\title{
Molecular surveillance of HCV mono-infection and HCV-HBV co-infection in symptomatic population at Hyderabad, Pakistan
}

\author{
Bushra B Patoli, Atif A Patoli, Nimerta Kumari Balani, Ashfaque A Korejo
}

Institute of Microbiology, University of Sindh, Jamshoro. Pakistan.

\section{Emails:}

Atif A Patoli- contact Email: atifpatoli@gmail.com

Nimerta Kumari Balani - Email: nimerta.kumari@usindh.edu.pk

Ashfaque A Korejo- Email: ashfaqueahmed2k10@gmail.com

\begin{abstract}
Background: Pakistan is endemic to hepatitis $\mathrm{B}$ and $\mathrm{C}$ infections. Alarming rise in hepatitis $\mathrm{C}$ virus (HCV) infection has been noticed in some areas of Sindh with an increasing risk for co-infection frequency in this region.

Objective: To estimate the burden of HBV/HCV infection in Hyderabad Pakistan.

Methods: ELISA and Nucleic acid Amplification test were performed to detect viruses. SPSS and online calculator were used for statistical analysis.

Results: From a total of 108 seropositive hepatitis patients, 36.1\% $(n=39)$ were found HCV RNA-positive. Non-significant differences were observed in the frequencies of HCV infection for both genders [OR=0.735, CI (95\%) 0.307-1.761, $\mathrm{p}<0.05]$. The percentage of HBV DNA detection among $108 \mathrm{HCV}$-seropositive cases was 17.9\% ( $\mathrm{n}=19)$. However, HCV-HBV co-infection in HCV-RNA positive cases was determined in $48.7 \%(\mathrm{n}=19)$ cases with non-significant difference in both genders [OR $=1.51$, CI $(95 \%)=0.38-5.96, \mathrm{p}<0.05]$. Analysis suggested weakly positive correlation between HCV mono-infection and HCV-HBV co-infection and age $(\mathrm{r}=0.184$, and $\mathrm{r}=0.1231)$, respectively.

Conclusion: The study demonstrates a high prevalence of HBV co-infection among active hepatitis $\mathrm{C}$ patients of Hyderabad. Keywords: HCV mono-infection, HCV-HBV co-infection, molecular surveillance, Nucleic acid Amplification Test, active hepatitis $\mathrm{C}$, Hyderabad, Sindh.
\end{abstract}

DOI: https://dx.doi.org/10.4314/ahs.v18i3.9

Cite as: Patoli BB, Patoli AA, Balani NK, Korejo AA. Molecular surveillance of HCV mono-infection and HCV-HBV co-infection in symptomatic population at Hyderabad, Pakistan. Afri Health Sci. 2018;18(3): 531-538. https:/ / dx.doi.org/10.4314/ahs.v18i3.9

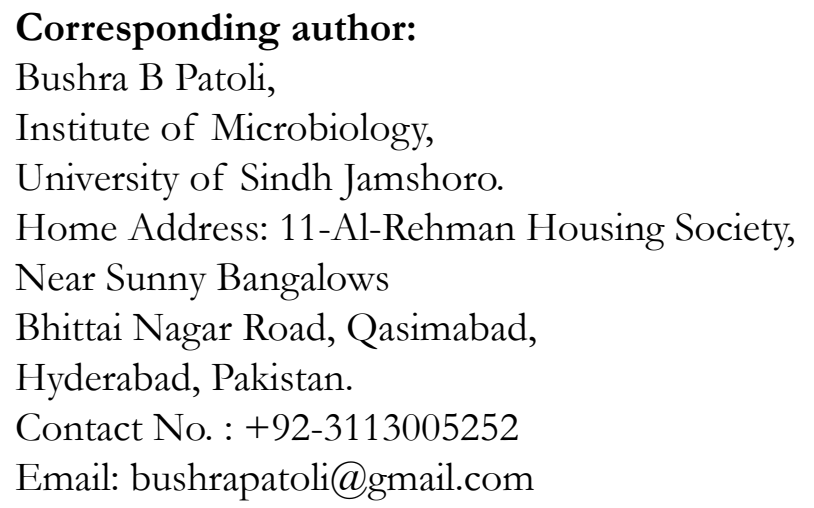

Corresponding author:

Bushra B Patoli, Institute of Microbiology, University of Sindh Jamshoro.

Home Address: 11-Al-Rehman Housing Society,

Near Sunny Bangalows

Bhittai Nagar Road, Qasimabad, Hyderabad, Pakistan.

Contact No. : +92-3113005252

Email: bushrapatoli@gmail.com

\section{Introduction}

Hepatitis B and Hepatitis C identified as the most prevalent causes of hepatitis in diverse groups of population including general population, health care workers, children and patients with short-term hepatitis and chronic liver diseases. Nearly 2 billion people are infected with Hepatitis B Virus (HBV) and the annual mortality rate approaches about 0.9 million around the world in people suffering from Hepatitis B associated complications ${ }^{1,2}$. Hepatitis $\mathrm{C}$ virus (HCV) is also one of the major sources of chronic hepatitis and affects about 71 million people

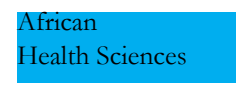

(C) 2018 Patoli et al. Licensee African Health Sciences. This is an Open Access article distributed under the terms of the Creative commons Attribution License (https://creativecommons.org/licenses/BY/4.0), which permits unrestricted use, distribution, and reproduction in any medium, provided the original work is properly cited. 
with the magnitude of about 0.4 million deaths annually around the world ${ }^{3,4}$.

Hepatitis B virus belong to Hepadnavirus family having a circular dsDNA genome with one nick, but, complete -ve DNA strand ( $3.2 \mathrm{~kb}$ in length). The other complementary strand is of +ve polarity and incomplete with a large gap, approximately $1.7 \mathrm{~kb}$ in length ${ }^{5}$. Although $\mathrm{HBV}$ vaccine was introduced more than three decades ago ${ }^{6}$, the infectivity ratio of hepatitis $\mathrm{B}$ is still exceedingly distressing, affecting around 350-400 million individuals with chronic infection worldwide, of whom $75 \%$ belong to Asia ${ }^{7-9}$. $\mathrm{HBV}$ infection is endemic to Pakistan with a seroprevalence of $2.4 \%$ (range $1.4-11.0 \%$ ) in healthy adults ${ }^{10,11}$ and $32.6 \%$ in patients with liver disease ${ }^{12}$. HBV infection approximately affects 9 million people in Pakistan ${ }^{13}$. HBV transmission mostly occurs through parenteral route, that is, unsafe blood transfusions and use of unsterilized or re-used syringes and needles ${ }^{10,11,13}$.

Hepatitis C Virus (HCV) is an enveloped, blood-borne infectious agent belongs to Flaviviridae family with ssRNA genome of positive polarity ${ }^{14}$. Hepatitis $\mathrm{C}$ is estimated to affect 171 million people worldwide with the global infectivity ratio of $\sim 3 \%{ }^{15-17}$. HCV is widely spread amongst the population of Pakistan with the mean sero-prevalence rate of $6.8 \%$ among healthy adults and infectivity ratio of more than $5 \%$ in the general population across the country ${ }^{17}$.

Nearly 10 million people in Pakistan are affected with Hepatitis $C$ infection ${ }^{18}$ and most of them belong to rural and periurban areas of Pakistan where the sources of HCV spread are relatively many, such as, routine practice of multiple injections, re-use of syringes, unsterilized use of needles in ear and nose piercing and lack of proper blood screening and transfusion procedures, etc. A high sero-prevalence of HCV up to $28.6 \%$ is described in asymptomatic individuals in Nausheroferoz district, Sindh, suggesting HCV is widely present in certain rural areas ${ }^{19}$. Because HCV and HBV share the same route of transmission and the chances of co-infection are likely more particularly in areas with high burden of infection by these viruses. Limited research reports are available to describe the co-infection frequency in different geographical regions of Pakistan and the data from Hyderabad and other areas of Sindh is actually scarce. HBV-HCV co-in- fection frequency is reported as $9 \%$ in hepatitis patients of Peshawar and Abbottabad cities of Pakistan ${ }^{20}$. In few other studies conducted in some rural areas of Punjab province, $\mathrm{HBsAg}$ and anti-HCV antibody was found in $0.19 \%$ in healthy blood donors ${ }^{21}$ and $3.2 \%$ in health care workers $^{22}$. The rural and urban areas in Sindh province, except the mega city Karachi, are largely investigated for the prevalence of mono-infection by HBV and HCV and lack a co-infection parameter ${ }^{19,23-25}$. A few studies conducted in Karachi show dual HBV-HCV prevalence as $0.11 \%$ in household children ${ }^{26}, 1.3 \%$ in viral hepatitis patients ${ }^{27}$ and $3.1 \%$ in patients of hepatitis $\mathrm{B}^{28}$. In one community based study Bhatti and Manzoor described 2.5\% dual HBV-HCV prevalence in rural areas of $\operatorname{Sindh}^{29}$. A previous study by Junejo et al. presented 3.9\% co-prevalence of HBsAg and anti-HCV infection in the ocular patients of $\mathrm{Hyderabad}^{30}$. In the present study, we investigated more than hundred hepatitis $\mathrm{C}$ seropositive samples from HCV patients of Hyderabad. All anti-HCV positive samples were processed for NAT to find out active HCV cases. HBV co-infection was tracked in both anti-HCV and HCV-RNA positive samples and the data obtained was correlated with age and gender for the statistical analysis. The data presented here describes the prevalence of HBV co-infection in the active HCV patients of Hyderabad city of Pakistan.

\section{Methods}

The study was approved by the Institutional Review Board [R.No.5 (60)] of University of Sindh, Jamshoro. In the present study, blood samples from hepatitis patients were collected and processed from Asian Institute of Medical Sciences (AIMS), one of the main diagnostic centers of Hyderabad. The minimum sample size for both mono and co-infections were determined to be 87 and 90 using the following parameters; the $Z$ value of standard normal distribution was calculated from $95 \%$ (CI) with a margin of error of $5 \%$, and about $6 \%$ of $\mathrm{HCV}$ active infection ${ }^{17}$ and $6.2 \%$ of HCV-HBV co-infection respectively ${ }^{10}$. A total of 108 non-duplicate samples from different age groups found positive for anti HCV antibodies on the basis of the Electro-Chemi-Luminescence Immunoassay (ECLIA) using Elecsys and Cobas e Immunoassay Analyzer were included in the current study. The samples were processed for Nucleic acid Am- 
plification Test to detect the HCV RNA and HBV DNA. The detection was performed on Cobas ${ }^{\circledR} 480$ System USA Hemilton (involving separate extraction and detection) using Cobas ${ }^{\circledR} \mathrm{HCV}$ and $\mathrm{HBV}$ test kit (Roche) as per manufacturer's instructions. The statistical analysis of data was either performed using SPSS IBM version 20 or using online statistics calculator [Select Statistical Services UK (www.select-statistics.co.uk) and Graph-pad prism (www.graphpad.com)].The variables categorized were further scrutinized using Fisher's exact test and bivariate correlation analysis.

\section{Results}

HCV RNA positive cases are independent of gender For the estimation of active HCV infection, an overall of
108 non-duplicate anti-HCV antibodies positive samples from hepatitis patients of different age groups were processed to detect HCV RNA using quantitative RT-PCR. A total of 79 samples $(74.5 \%)$ from male and 29 samples $(27.3 \%)$ from female patients were processed. The overall percentage of HCV RNA-positive and negative samples was found to be $36.1 \%(n=39)$ and $63.9 \%(n=67)$ respectively (Figure 1). Categorically, a total of $12(34.1 \%)$ cases among females and $27(41.3 \%)$ among males were found to be positive (Table 1, Figure 2). The OR with CI (95\%) for gender was calculated to be 0.735 (CI 95\% $=0.307$ 1.761), while the p-values using a Fisher's exact test was determined to be 0.490 at $\alpha=0.05$, suggesting statistically non-significant differences in the frequencies of HCV infection among both genders.

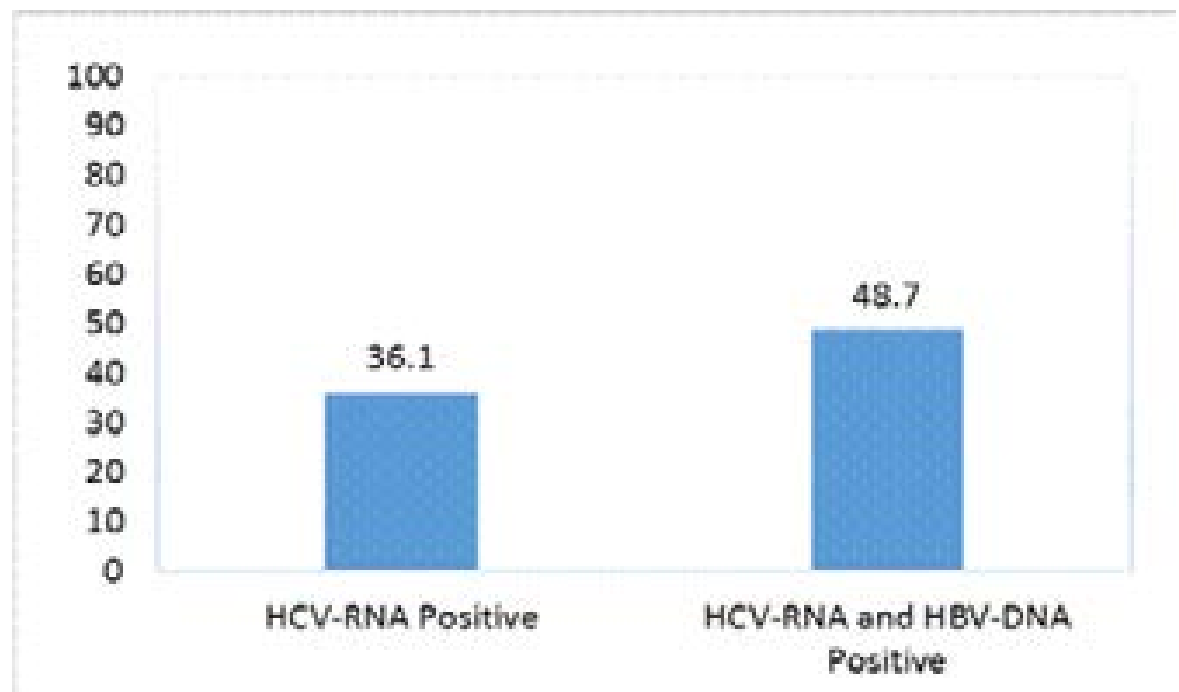

\section{Figure 1. Bar diagram displaying the percentages of HCV mono-infection}

and HCV-HBV co-infection.

Age and HCV RNA positive cases have a weak positive correlation.

To explore if age has any correlation with HCV-RNA positive cases, a Pearson's correlation co-efficient between age and HCV RNA positive cases was calculated to be $\mathrm{r}=0.184$, suggesting a weakly positive correlation between age and HCV RNA positive cases. We also categorized the data into various age groups. The magnitude of the age group was randomly chosen to be 10 . Table 1 displays the number of HCV-RNA positive and negative cases for different age groups in each category and is expressed both in absolute and relative values (percentages). The OR, CI (95\%), and p-values calculated for various age groups gender-wise are also shown in Table 1.

African Health Sciences Vol 18 Issue 3, September, 2018
The maximum active HCV percentage in male category was found in the age group of $61-70$ years $(60 \%)$ while in case of female category the maximum active HCV percentage was seen in the age group of 11-20 years (100\%). However due to very small number of samples the comparative analysis could not be performed for these age groups. In order to avoid bias, the age groups having mathematically substantial sample size (i.e. age groups ranging from 21 to 60) were then compared for both genders. The highest positive cases $(66.6 \%)$ were seen for female category in the age group of 41-50, however, statistically non-significant differences for HCV-RNA positive cases between male and female were found in various age groups. 
Table 1. Percentages of HCV-RNA positive and negative cases among male and female gender and age groups. The Odds ratio (OR), CI (95\%) and p-values are mentioned for various age groups, gender-wise. $n=$ number, $N A=$ Not Applicable.

\begin{tabular}{|c|c|c|c|c|c|c|c|c|c|}
\hline Gender & $\begin{array}{l}\text { HCV- } \\
\text { RNA }\end{array}$ & $\begin{array}{l}1-10 \\
\text { n (\%) }\end{array}$ & $\begin{array}{l}11-20 \\
\text { n (\%) }\end{array}$ & $\begin{array}{l}21-30 \\
\text { n (\%) }\end{array}$ & $\begin{array}{l}31-40 \\
n(\%)\end{array}$ & $\begin{array}{l}41-50 \\
\text { n (\%) }\end{array}$ & $\begin{array}{l}51-60 \\
\text { n (\%) }\end{array}$ & $\begin{array}{l}61-70 \\
\text { n (\%) }\end{array}$ & $\begin{array}{l}71-80 \\
\text { n (\%) }\end{array}$ \\
\hline \multirow[t]{3}{*}{ Male } & Positive & 0 (NA) & 0 (NA) & $\begin{array}{l}2(13.3 \%) \\
13\end{array}$ & $\begin{array}{l}11 \\
(37.9 \%) \\
18\end{array}$ & $7(33.3 \%)$ & $4(50 \%)$ & $3(60 \%)$ & 0 (NA) \\
\hline & Negative & 0 (NA) & 0 (NA) & $(86.7 \%)$ & $(62.1 \%)$ & $14(66.7 \%)$ & $4(50 \%)$ & $2(40 \%)$ & 1 (NA) \\
\hline & Total & 0 & 0 & 15 & 29 & 21 & 8 & 5 & 1 \\
\hline \multirow[t]{4}{*}{ Female } & Positive & 0 (NA) & $2(100 \%)$ & $5(45.4 \%)$ & $1(12.5 \%)$ & $2(66.6 \%)$ & $2(40 \%)$ & 0 (NA) & 0 (NA) \\
\hline & Negative & 0 (NA) & $0(00 \%)$ & $6(54.6 \%)$ & $7(87.5 \%)$ & $1(33.4 \%)$ & $3(60 \%)$ & 0 (NA) & 0 (NA) \\
\hline & Total & 0 & 2 & 11 & 8 & 3 & 5 & 0 & 0 \\
\hline & $\begin{array}{l}\text { OR } \\
{[C I} \\
(95 \%)] \\
\text { p-value } \\
(\alpha= \\
0.05)=\end{array}$ & {$[\mathrm{NA}]$} & [NA] & $\begin{array}{l}0.18 \\
{[0.03} \\
1.24]\end{array}$ & $\begin{array}{l}4.30 \\
{[0.46} \\
39.6]\end{array}$ & $\begin{array}{l}0.75 \\
{[0.1-5.58]}\end{array}$ & $\begin{array}{l}1.5 \\
{[0.16-14.4]}\end{array}$ & [NA] & {$[\mathrm{NA}]$} \\
\hline
\end{tabular}

HCV-HBV co-infection is independent of gender

To determine the co-infection frequency, HCV sero-positive samples $(n=106)$ were further processed in combination with Hepatitis B virus detection. Out of $39 \mathrm{HCV}$ RNA positive samples, $19(48.7 \%)$ were found to be positive for HCV-HBV co-infection, while 20 (51.3\%) were negative for co-infection. (Figure 1). Categorically, a total of 14/27 (51.8\%) cases among male and 05/12 (41.6\%) among female were calculated to be positive for HCVHBV co-infection (Table 2, Figure 2). The OR with CI $(95 \%)$ for gender was calculated to be $1.51 \mathrm{CI}(95 \%)=$ (0.38 - 5.96), while the p-values using a Fisher's exact test was determined to be 0.731 at $\alpha=0.05$, suggesting an impartial effect of gender on the HCV-HBV co-infection.

Table 2. Percentages of HCV-HBV-RNA positive and negative cases among male and female gender and age groups. The odds ratio (OR), CI (95\%) and p-values are mentioned for various age groups, gender-wise. $n=$ number, NA = Not Applicable, $\mathrm{Co}-\mathrm{CB}=\mathrm{HCV}-\mathrm{HBV}$ Co-infection.

\begin{tabular}{|c|c|c|c|c|c|c|c|c|c|}
\hline Gender & $\begin{array}{l}\text { HCV-HBV } \\
\text { Co-infection }\end{array}$ & $\begin{array}{l}1-10 \\
\text { n (\%) }\end{array}$ & $\begin{array}{l}11-20 \\
n(\%)\end{array}$ & $\begin{array}{l}21-30 \\
\text { n (\%) }\end{array}$ & $\begin{array}{l}31-40 \\
\text { n (\%) }\end{array}$ & $\begin{array}{l}41-50 \\
\text { n (\%) }\end{array}$ & $\begin{array}{l}51-60 \\
\text { n (\%) }\end{array}$ & $\begin{array}{l}61-70 \\
\text { n (\%) }\end{array}$ & $\begin{array}{l}71-80 \\
\text { n (\%) }\end{array}$ \\
\hline \multirow[t]{2}{*}{ Male } & $\begin{array}{l}\text { Co-CB } \\
\text { Non-Co-CB }\end{array}$ & $\begin{array}{l}0 \text { (NA) } \\
0 \text { (NA) }\end{array}$ & $\begin{array}{l}0 \text { (NA) } \\
0 \text { (NA) }\end{array}$ & $\begin{array}{l}2(13.3 \%) \\
13(86.7 \%)\end{array}$ & $\begin{array}{l}5(17.2 \%) \\
24 \\
(82.8 \%)\end{array}$ & $\begin{array}{l}2(10 \%) \\
18(90 \%)\end{array}$ & $\begin{array}{l}3(37.5 \%) \\
5(62.5 \%)\end{array}$ & $\begin{array}{l}2(40 \%) \\
3(60 \%)\end{array}$ & $\begin{array}{l}0(00 \%) \\
1 \\
(100 \%)\end{array}$ \\
\hline & Total & 0 & 0 & 15 & 29 & 20 & 8 & 5 & 1 \\
\hline \multirow[t]{2}{*}{ Female } & $\begin{array}{l}\text { Co-CB } \\
\text { Non-Co-CB }\end{array}$ & $\begin{array}{l}0 \text { (NA) } \\
0 \text { (NA) }\end{array}$ & $\begin{array}{l}1(50 \%) \\
1(50 \%)\end{array}$ & $\begin{array}{l}2(18.8 \%) \\
9(81.8 \%)\end{array}$ & $\begin{array}{l}0(0 \%) \\
7(100 \%)\end{array}$ & $\begin{array}{l}1(33.3 \%) \\
2(66.7 \%)\end{array}$ & $\begin{array}{l}1(20 \%) \\
4(80 \%)\end{array}$ & $\begin{array}{l}0 \text { (NA) } \\
0(\mathrm{NA})\end{array}$ & $\begin{array}{l}0 \text { (NA) } \\
0 \text { (NA) }\end{array}$ \\
\hline & $\begin{array}{l}\text { Total } \\
\text { OR } \\
{[\text { CI }(95 \%)]} \\
\text { p-value } \\
(\alpha=0.05)\end{array}$ & $\begin{array}{l}{[\mathrm{NA}]} \\
{[\mathrm{NA}]}\end{array}$ & [NA] & $\begin{array}{l}11 \\
0.69 \\
{[0.08-5.86]}\end{array}$ & {$[\mathrm{NA}]$} & $\begin{array}{l}3 \\
0.22 \\
{[0.01-3.89]}\end{array}$ & $\begin{array}{l}5 \\
2.4 \\
{[0.18-32.88]}\end{array}$ & {$[\mathrm{NA}]$} & {$[\mathrm{NA}]$} \\
\hline
\end{tabular}




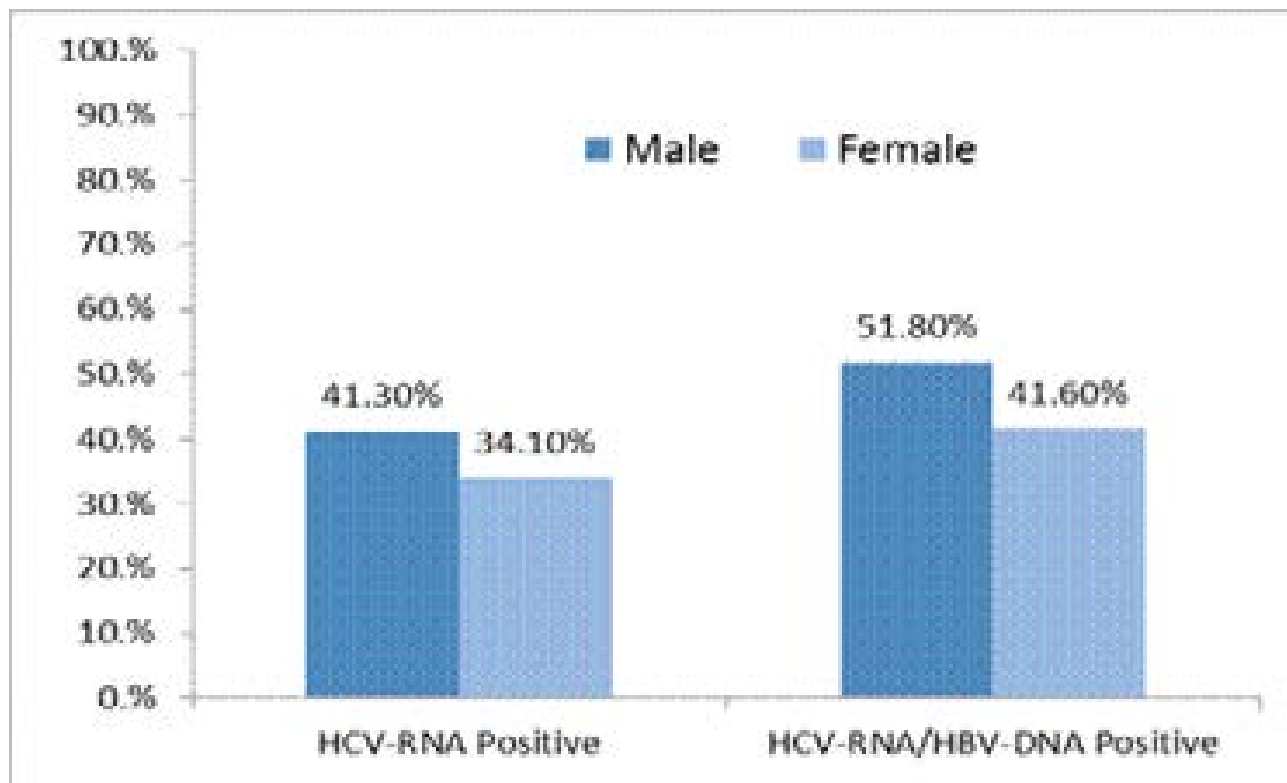

\section{Figure 2. Bar diagram displaying the percentages of HCV mono-infection and HCV-HBV co-infection in both genders.}

\section{Age and HCV-HBV co-infection cases have a weak positive correlation.}

To explore if age has any correlation with HCV-HBV co-infection, a Pearson's correlation co-efficient between age and HCV-HBV co-infection cases was calculated to be $\mathrm{r}=0.1231$, suggesting a weakly positive correlation between age and HCV-HBV co-infection cases. We also categorized the data into various age groups. Once again the magnitude of the age group was randomly chosen to be 10. The Table 2 displays the numbers of HCV-HBV co-infection cases for different age groups in each category and is expressed both in absolute and relative values (percentages). Table 2 also shows the OR, CI (95\%), and p-values calculated for various age groups gender-wise. The maximum percentage HCV-HBV co-infection frequency in male category was found in the age group of $61-70$ years $(40 \%)$ while in case of female category the maximum $\mathrm{HCV}-\mathrm{HBV}$ coinfection frequency was seen in the age group of $11-20$ years $(50 \%)$. However due to very small numbers of samples the comparative analysis could not be performed for these age groups. In order to avoid bias, the age groups having mathematically substantial sample size (i.e. age groups ranging from 21 to 60) were then compared for both genders. The highest positive cases $(37.5 \%)$ for $\mathrm{HCV}-\mathrm{HBV}$ co-infection were seen for male category in the age group of 51-60, however, statistically non-significant differences for HCV-HBV co-infection cases between male and female were found in various age groups.

\section{Discussion}

Pakistan is one of the worst affected countries with the highest burden of hepatitis $B$ and hepatitis $C$ viral infection. According to World Health Organization (WHO) report, nearly 12 million people in Pakistan are suffering from hepatitis $\mathrm{B}$ or $\mathrm{C}$ infections and the number is on continuous rise each year. In hepatitis $\mathrm{B}$ and $\mathrm{C}$ endemic countries, dual HBV and HCV infection constitute a significant number of patients. Infection with more than one hepatitis virus further aggravates the chronicity of disease in the population particularly with low socio-economic status. Co-infection of HBV and HCV has been reported from different countries of world as these viruses share the same route of transmission ${ }^{31-33}$. Patients with dual hepatitis are more susceptible and at greater risk of developing liver cirrhosis and hepatocellular carcinoma ${ }^{31}$. Anti-HCV prevalence is reported 5\% and HBsAg as 2.4\% in general population of Pakistan ${ }^{26}$. However, prevalence of hepatitis B and C varies in different geographical locations of Pakistan, depending upon the extent of expo- 
sure to the common risk factors, awareness and access of community to proper public health services. For example, in some rural areas of Sindh, HBV and HCV frequency was observed as $13 \%$ and $22 \%$ in pregnant woman and blood donors, respectively ${ }^{34}$. In few other studies exposure of HCV is observed even greater than $25 \%$ in the asymptomatic people of upper $\operatorname{Sindh}^{19,35}$ reflecting the fact that actual burden of disease need to be measured and it varies with localities within the same province. It has been studied that among the patients of chronic liver disease, $\mathrm{HBV}$ mono-infection prevalence is $10-46 \%$, anti-HCV is $40-60 \% 24$ and co-infection frequency of hepatitis B and $\mathrm{C}$ virus is $1-3 \%{ }^{27,28}$.

In the current study, active HCV mono-infection was found in 36.1\% cases and were simultaneously tracked for co-infection with HBV using NAT. Overall co-infection prevalence was observed as $17.9 \%$ in total anti-HCV positive samples $(\mathrm{n}=108)$ and $48 \%$ in HCV-RNA positive samples. This is a significantly higher frequency of dual infection in comparison to previous studies in the same or different regions of Pakistan. However, keeping in mind the higher frequency of exposure $(>25 \%)$ to both hepatitis B and C in rural areas of upper Sindh ${ }^{19,35}$, we presume that in hepatitis patients the chances for holding HBV and HCV dual infection are greater. In our study, we did not observe a significant statistical difference between single or dual infection of $\mathrm{HBV} / \mathrm{HCV}$ and gender. Some studies have shown that males have a high percentage of infectivity as compared to the females but lack significant statistical values ${ }^{24,27}$. As has been described by others ${ }^{24,35-37}$, we also observed in our study that frequency of mono or dual hepatitis increases with age and the maximum frequency $(37.5 \%)$ is seen in age group of 51 60. However the small sample size is a limitation of the present study but it strongly upholds the view that there is an alarmingly high prevalence of single or dual HBV/ HCV infection in the indigenous population of Hyderabad. The study provides a future direction to explore the common associated risk factors and a molecular surveillance with an increased sample size to estimate mono-infection and co-infection frequency in this region.

\section{Conclusion}

From the present study, we perceive that prevalence of
HBV and HCV is widespread among the population but the actual burden of disease is still not explored well in both symptomatic and asymptomatic individuals of $\mathrm{Hy}-$ derabad region. HCV is more widespread than HBV infection perhaps due to the lack of vaccine for $\mathrm{HCV}$ virus. Most of the studies conducted in rural or urban areas of Sindh are based on serological methods rather than molecular detection of viral nucleic acid to measure the actual prevalence of disease. Therefore it is suggested that access to an accurate diagnosis should be provided to the poor population for the estimation of true positive / active HCV infection, proper management and prevention of chronic illness.

\section{Acknowledgments}

We are thankful to Asian Institute of Medical Sciences (Diagnostic center, Hyderabad) for their help and providing space to perform the laboratory work. We are also thankful to University of Sindh for facilitating us to execute this research study.

\section{Funding}

This work was supported by the University of Sindh, Jamshoro.

\section{Conflicts of interest}

None.

\section{References}

1. Lavanchy D. Hepatitis B virus epidemiology, disease burden, treatment, and current and emerging prevention and control measures. Journal of Viral Hepatitis. 2004;11(2):97-107.

2. World Health Organization. Hepatitis B fact sheet July 2017. Accessed on January 2018.

3. Waheed Y. Hepatitis C eradication: A long way to go. World Journal of Gastroenterology. 2015;21(43):12510-2.

4. World Health Organization. Hepatitis C fact sheet. 2017; October. Accessed on January 2018.

5. Delius H, Gough NM, Cameron CH, Murray K. Structure of the hepatitis B virus genome. Journal of Virology. 1983;47(2):337-43.

6. Beasley RP, Hwang LY, Lee GC, Lan CC, Roan CH, Huang FY, et al. Prevention of perinatally transmitted hepatitis B virus infections with hepatitis B immune glob- 
ulin and hepatitis B vaccine. Lancet. 1983;2(8359):1099102. PubMed.

7. Blakely TA, Bates MN, Baker MG, Tobias M. Hepatitis $B$ carriage explains the excess rate of hepatocellular carcinoma for Maori, Pacific Island and Asian people compared to Europeans in New Zealand. International Journal of Epidemiology. 1999;28(2):204-10.

8. Andre F. Hepatitis B epidemiology in Asia, the Middle East and Africa. Vaccine. 2000;18 Suppl 1:S20-2.

9. AlamMM, Zaidi SZ, Malik SA, Naeem A, Shaukat S, Sharif S, et al. Serology based disease status of Pakistani population infected with hepatitis B virus. BMC Infectious Diseases. 2007;7:64.

10. Riaz MN, Faheem M, Anwar MA, Raheel U, Badshah Y, Akhtar H, et al. PCR-Based Molecular Diagnosis of Hepatitis Virus (HBV and HDV) in HCV Infected Patients and Their Biochemical Study. Journal of Pathogens. 2016;2016:3219793.

11. Abbas Z, Afzal R. Addressing viral hepatitis in Pakistan: not all is gloom and doom. Journal of the College of Physicians and Surgeons--Pakistan: JCPSP. 2014;24(2):75-7. PubMed.

12. Ahmed W, Qureshi H, Arif A, Alam SE. Changing trend of viral hepatitis--"A twenty one year report from Pakistan Medical Research Council Research Centre, Jinnah Postgraduate Medical Centre, Karachi". JPMA The Journal of the Pakistan Medical Association. 2010;60(2):86-9. 13. Ali M, Idrees M, Ali L, Hussain A, Ur Rehman I, Saleem $\mathrm{S}$, et al. Hepatitis B virus in Pakistan: a systematic review of prevalence, risk factors, awareness status and genotypes. Virology Journal. 2011;8:102.

14. Takamizawa A, Mori C, Fuke I, Manabe S, Murakami S, Fujita J, et al. Structure and organization of the hepatitis $\mathrm{C}$ virus genome isolated from human carriers. Journal of Virology. 1991;65(3):1105-13.

15. Lavanchy D. The global burden of hepatitis C. Liver international: Official Journal of the International Association for the Study of the Liver. 2009;29 Suppl 1:74-81.

16. Alter MJ. Epidemiology of hepatitis $C$ virus infection. World Journal of Gastroenterology. 2007;13(17):2436-41.

17. Umer M, Iqbal M. Hepatitis $C$ virus prevalence and genotype distribution in Pakistan: Comprehensive review of recent data. World Journal of Gastroenterology. 2016;22(4):1684-700.

18. Waheed Y, Shafi T, Safi SZ, Qadri I. Hepatitis C vi- rus in Pakistan: a systematic review of prevalence, genotypes and risk factors. World Journal of Gastroenterology. 2009;15(45):5647-53.

19. Aziz S, Khanani R, Noorulain W, Rajper J. Frequency of hepatitis B and C in rural and periurban Sindh. JPMA The Journal of the Pakistan Medical Association. 2010; 60(10):853-7.

20. Faiz Ur R, Khan J, Fida Z, Parvez A, Rafiq A, Syed S. Identifiable risk factors in hepatitis B and C. Journal of Ayub Medical College, Abbottabad: JAMC. 2011;23(4):22-3.

21. Khokhar N, Gill ML, Malik GJ. General seroprevalence of hepatitis $C$ and hepatitis B virus infections in population. Journal of the College of Physicians and Surgeons Pakistan: JCPSP. 2004;14(9):534-6. PubMed.

22. Sarwar J, Gul N, Idris M, Anis ur R, Farid J, Adeel MY. Seroprevalence of hepatitis B and hepatitis C in health care workers in Abbottabad. Journal of Ayub Medical College, Abbottabad: JAMC. 2008;20(3):27-9. PubMed.

23. Bosan A, Qureshi H, Bile KM, Ahmad I, Hafiz R. A review of hepatitis viral infections in Pakistan. JPMA The Journal of the Pakistan Medical Association. 2010;60(12):104558.

24. Qureshi H, Bile KM, Jooma R, Alam SE, Afridi HU. Prevalence of hepatitis B and C viral infections in Pakistan: findings of a national survey appealing for effective prevention and control measures. Eastern Mediterranean Health Journal $=\mathrm{La}$ revue de sante de la Mediterranee orientale = al-Majallah al-sihhiyah li-sharq al-mutawassit. 2010;16 Suppl:S15-23.

25. Bibi S, Dars S, Ashfaq S, Ara Qazi R, Akhund S. Seroprevalence and risk factors for hepatitis $\mathrm{C}$ virus (HCV) infection in pregnant women attending public sector tertiary care hospital in Hyderabad Sindh. Pakistan Journal of Medical Sciences. 2013;29(2):505-8.

26. Jafri W, Jafri N, Yakoob J, Islam M, Tirmizi SF, Jafar $\mathrm{T}$, et al. Hepatitis B and C: prevalence and risk factors associated with seropositivity among children in Karachi, Pakistan. BMC Infectious Diseases. 2006;6:101.

27. Khan J, Shafiq M, Mushtaq S, Ayaz S, Ullah R, AbdEI-Salam NM, et al. Seropositivity and Coinfection of Hepatitis B and C among Patients Seeking Hospital Care in Islamabad, Pakistan. BioMed Research International. 2014;2014:4.

28. Baig S, Siddiqui AA, Ahmed WU, Qureshi H, Arif A. Frequency of hepatitis C and D super infection in 
patients with hepatitis B related complex liver disorders. Journal of the College of Physicians and Surgeons--Pakistan: JCPSP. 2009;19(11):699-703.

29. Bhatti S, Manzoor S. Molecular epidemiology and clinical features of Hepatitis C Virus (HCV) in epidemic areas of Interior Sindh, Pakistan. Pakistan Journal of Medical Sciences. 2016;32(5):1279-82.

30. Junejo SA, Khan N, Lodhi AA. Prevalence of Hepatitis $B$ and $C$ infection in patients admitted at Tertiary Eye Care Centre: A Hospital based study. Paksitan Journal of Medical Sciences. 2009;25(4):597-600.

31. Donato F, Boffetta P, Puoti M. A meta-analysis of epidemiological studies on the combined effect of hepatitis $\mathrm{B}$ and $\mathrm{C}$ virus infections in causing hepatocellular carcinoma. International Journal of Cancer. 1998;75(3):34754.

32. Raimondo G, Brunetto MR, Pontisso P, Smedile A, Maina AM, Saitta C, et al. Longitudinal evaluation reveals a complex spectrum of virological profiles in hepatitis $\mathrm{B}$ virus/hepatitis $\mathrm{C}$ virus-coinfected patients. Hepatology. 2006;43(1):100-7. PubMed

33. Liaw YF, Chen YC, Sheen IS, Chien RN, Yeh CT, Chu $\mathrm{CM}$. Impact of acute hepatitis $\mathrm{C}$ virus superinfection in patients with chronic hepatitis B virus infection. Gastroenterology. 2004;126(4):1024-9. PubMed

34. AA Ghanghro, GL. Ghanghro. High prevalence of hepatitis $\mathrm{C}$ and hepatitis $\mathrm{B}$ infection among pregnant women and their blood donors District Naushahro Feroze, Pakistan Journal of Emergency Medicine, Trauma \& Acute Care, International Conference in Emergency Medicine and Public Health - Qatar 2016. 2014;32.

35. Abbas Z, Jeswani NL, Kakepoto GN, Islam M, Mehdi K, Jafri W. Prevalence and mode of spread of hepatitis B and C in rural Sindh, Pakistan. Tropical gastroenterology: Official Journal of the Digestive Diseases Foundation. 2008;29(4):210-6.

36. Janjua NZ, Hamza HB, Islam M, Tirmizi SF, Siddiqui A, Jafri W, et al. Health care risk factors among women and personal behaviours among men explain the high prevalence of hepatitis $C$ virus infection in Karachi, Pakistan. Journal of Viral Hepatitis. 2010;17(5):317-26.

37. Ahmed F, Irving WL, Anwar M, Myles P, Neal KR. Prevalence and risk factors for hepatitis $\mathrm{C}$ virus infection in Kech District, Balochistan, Pakistan: most infections remain unexplained. A cross-sectional study. Epidemiology and infection. 2012;140(4):716-23. 